\title{
Effects of Adrenodemedullation on In Vivo Insulin- Stimulated Glucose Utilization in Relation to Glycolysis in Rat Peripheral Tissue
}

\author{
YoshiHARU OSHIDA, ISAO OHSAWA, \\ JUICHI SATO AND Yuzo SATO \\ Research Center of Health, Physical Fitness and Sports, Nagoya \\ University, Nagoya 464-01, Japan
}

\begin{abstract}
The effect of adrenodemedullation (ADMX) on insulin action was examined in anesthetized rats by means of a three-step euglycemic clamp procedure (insulin infusion rate: $0,6.0$ and 30.0 $\mathrm{mU} \cdot \mathrm{kgBW}^{-1} \cdot \mathrm{min}^{-1}$ ) combined with a microdialysis technique in skeletal muscle and adipose tissue. The dialysate lactate levels in the above tissues increased in parallel with the plasma lactate levels during the sequential euglycemic clamp. In the euglycemic clamp, the glucose infusion rate (GIR) was significantly $(P<0.01)$ higher in ADMX rats $\left(13.41 \pm 0.82 \mathrm{mg} \cdot \mathrm{kgBW}^{-1} \cdot \mathrm{min}^{-1}\right)$ than in SHAM rats $(10.21 \pm 0.87$ $\mathrm{mg} \cdot \mathrm{kgBW}^{-1} \cdot \mathrm{min}^{-1}$ ) during the $6.0-\mathrm{mU} \cdot \mathrm{kgBW}^{-1} \cdot \mathrm{min}^{-1}$ insulin infusion, and the lack of a significant difference between ADMX and SHAM rats was observed during the $30-\mathrm{mU} \cdot \mathrm{kgBW}^{-1} \cdot \mathrm{min}^{-1}$ insulin infusion. In skeletal muscle, the concentration of lactate in dialysate was significantly higher in ADMX rats $(9.29 \pm 1.01 \mathrm{mg} / \mathrm{d} l)$ than in SHAM rats $(6.22 \pm 0.47 \mathrm{mg} / \mathrm{d} l)(P<0.05)$ at an insulin infusion rate of $6.0 \mathrm{mU} \cdot \mathrm{kgBW}^{-1} \cdot \mathrm{min}^{-1}$. In adipose tissue, no significant difference in dialysate lactate levels was found between ADMX and SHAM rats at any insulin infusion rate. These results suggest that 1 ) it is possible to determine insulin action in skeletal muscle and adipose tissue in vivo by using the microdialysis technique, that 2) ADMX appears to result in a significant increase in insulin sensitivity, and that 3) lactate formation increased in skeletal muscle, but not in adipose tissue.
\end{abstract}

Key words: Adrenodemedullation, Insulin sensitivity, Euglycemic clamp, Microdialysis, Glycolysis.

(Endocrine Journal 40: 99-106, 1993)

PREVIOUS studies demonstrated that epinephrine inhibited insulin secretion [1,2] and augmented hepatic glucose output by stimulating gluconeogenesis [3] and glycogenolysis [4]. In vitro studies employing skeletal muscle showed that epinephrine also impaired glucose uptake [5]. In contrast, Racotta et al. [6] reported no significant changes in plasma glucose concentrations in rats during 7 days of norepinephrine infusion. More recent studies have indicated that norepinephrine synergistically potentiates brown adipocyte sub-

Received: June 25, 1992

Accepted: December 10, 1992

Correspondence to: Dr. Yoshiharu OSHIDA, Research Center of Health, Physical Fitness and Sports, Nagoya University, Furo-cho, Chikusa-ku, Nagoya 464- 01, Japan maximal insulin response for glucose transport in rat [7], and that chronic $\beta$-adrenoreceptor stimulation with norepinephrine increases insulin-stimulating glucose disposal in vivo by increasing the insulin sensitivity of rat peripheral tissues [8].

It has been known that plasma levels of norepinephrine are increased and those of epinephrine are decreased one week after ADMX in rats [9]. Under these conditions it could be hypothesized that insulin-stimulated glucose uptake is increased in peripheral tissue in vivo considering the above previous reports $[7,8,9]$. In order to confirm this hypothesis, we have used a sequential euglycemic hyperinsulinemic clamp technique, adapted in our laboratory for use in rats, in combination with a microdialysis technique 
which is developed for in situ measurements of extracellular levels of neurotransmitters in rat brain by Ungerstedt $e t a l$. $[10,11]$ and has recently been proven to be a practicable method for in vivo determination of substances in adipose tissue [12, 13].

\section{Materials and Methods}

\section{Materials}

Twenty-four male albino Wistar rats (Chubu Kagaku Shizai Co., Ltd., Nagoya, Japan), weighing $200-250 \mathrm{~g}$, were housed in individual cages in a temperature $\left(20-22^{\circ} \mathrm{C}\right)$ and light-controlled (12:12h light-dark cycle) room and had free access to laboratory food and water. Six rats were used for the preparatory examination. One week before the experiment, 8 rats were surgically adrenodemedullated (ADMX) according to Yatomi et al. [14], who had already shown that the adrenocortex was intact. The others were sham operated (SHAM).

\section{Experimental procedure}

On the experimental day after an overnight fast, the rats were anesthetized with sodium pentobarbital $(60 \mathrm{mg} / \mathrm{kg}$ i.p.) and a rectal thermometer was introduced. The rectal temperature was kept at $37^{\circ} \mathrm{C}$ by adjusting the distance of a heating lamp. All studies were carefully performed by the same investigator so as not to be anoxic. A right jugular venous catheter (PE-50) was inserted for infusion of $20 \%$ glucose solution and insulin (Pork monocomponent insulin, NOVO Industry, Denmark). Thereafter, a subcutaneous incision over both thighs was performed to expose the muscle tissue. The muscle fascia above the knee joint was punctured with a fine needle, and the microdialysis probe (Carnegie Medicin, Sweden) was gently inserted into the deep part of the M. quadriceps femoris, vastus lateralis (red muscle). The probes were also placed in both inguinal adipose tissues. There was no movement of the legs during the experimental period. The microdialysis probe consisted of a tubular membrane (polycarbonate, outer diameter $0.5 \mathrm{~mm}$; length $10 \mathrm{~mm}$; molecular weight cut-off; 5,000-20,000). During microdialysis the probe was connected to a microinfusion pump (CMA/100, Carnegie Medicin, Sweden) and continuously perfused at $1 \mu \mathrm{l} / \mathrm{min}$ with KrebsHenseleit bicarbonate (KHB) buffer (except that the $\mathrm{Ca}^{2+}$ concentration was reduced from 5 to 2.5 $\mathrm{mEq} / l)$. The perfusate was carried to the distal end by a fine cannula inside the probe, flowing back between the membrane and the inner cannula in a retrograde direction, and was the collected at the outlet of the probe. The in vitro recovery of lactate (dialysate concentration $v s$. medium concentration $\times 100$ ) was $60.8 \pm 1.2 \%$ at a perfusate flow rate of 1 $\mu \mathrm{l} / \mathrm{min}$. The term 'recovery' is defined as the ratio of the concentration of a substance at the dialysate outlet to that of the same substance in the solution outside the probe. Probes were placed in media containing varying concentrations of lactate $(1.80-30.00 \mathrm{mg} / \mathrm{d} l)$ and were continuously perfused with KHB buffer at $1 \mu \mathrm{l} / \mathrm{min}$. Dialysate concentrations of lactate were determined in triplicate at each concentration. The recovery remained constant at the lactate concentration of up to at least $30.00 \mathrm{mg} / \mathrm{d} l$.

To obtain stable tissue diffusion conditions an equilibration period of $60 \mathrm{~min}$ was always allowed before starting the actual experiments. Then, a three-step sequential euglycemic clamp procedure (insulin infusion rate: $0,6.0$ and $30.0 \mathrm{mU}$. $\mathrm{kgBW}^{-1} \cdot \mathrm{min}^{-1}$ ) combined with a microdialysis study in femoral muscle and adipose tissue was performed in the anesthetized rats. The insulin infusion rate was changed every $75 \mathrm{~min}$. The blood glucose concentration, which was measured in samples from the tail vein, was kept at the basal level by determination of blood glucose 5-15 min and empirically adjusting the infusion rate of a $20 \%$ glucose solution. Under these steady-state conditions of euglycemia (insulin infusion rate: 6.0 and $30.0 \mathrm{mU} \cdot \mathrm{kgBW}^{-1} \cdot \mathrm{min}^{-1}$ ), all of the infused glucose was taken up by cells and provided a measure of the overall tissue action to insulin, because these plasma insulin concentrations had been shown to inhibit hepatic glucose production in both chronic norepinephrine-treated and -untreated anesthetized rats [8]. The rate of insulinmediated glucose uptake (glucose infusion rate, GIR) was thus determined by the steady-state blood glucose and insulin concentrations during the euglycemic clamp. The mean of values from 45 to $75 \mathrm{~min}$ for the three insulin infusion rates was employed, because a plateau glucose infusion rate was achieved. The blood samples for deter- 
mination of plasma insulin levels and blood lactate concentrations in the preparatory examination were drawn from the tail veins at $60 \mathrm{~min}$ for the three insulin infusion rates. On the other hand, the microdialysis probes were perfused with KHB buffer at $1 \mu \mathrm{l} / \mathrm{min}$ and the dialysates were collected every $15 \mathrm{~min}$ for analysis of lactate. The average lactate values in the dialysate during the 45 to 75-min steady-state period are shown. Before the rats were sacrificed, the blood was taken from the orbital vein to measure the plasma concentration of catecholamines.

\section{Analytical methods}

Blood glucose concentrations were determined with a YSI 23A glucose analyzer (Yellow Springs Instrument, $\mathrm{OH}, \mathrm{USA}$ ), plasma insulin by radioimmunoassay [15], plasma catecholamines (epinephrine and norepinephrine) by highperformance liquid chromatography (Bio-Science, CA, USA) [16] and lactate enzymatically (Detaminer LA, Kyowa Medex, Tokyo, Japan) with an automatic analyzer (Hitachi 706, Hitachi Co., Ltd., Tokyo, Japan). The blood samples were immediately separated into plasma and cell portions in a centrifuge $(3,000 \mathrm{rpm}, 20 \mathrm{~min})$ at $4^{\circ} \mathrm{C}$ and stored at $-70^{\circ} \mathrm{C}$ until analysis. The cell compartment after plasma separation was suspended in saline and returned to the rat so as not to reduce hematocrit.

All data were expressed as the mean \pm SEM. Statistical analysis was performed by analysis of variance or Student's $t$-test, as appropriate. Differences were considered significant when $P<0.05$.

\section{Results}

1. Relationship between dialysate and blood lactate concentrations during the euglycemic clamp (Preparatory experiment)

In order to demonstrate that the microdialysis technique in combination with the euglycemic clamp study was useful to evaluate insulin action in the whole-body and in individual tissues (skeletal muscle and adipose tissue), the blood and dialysate lactate concentrations were measured. Plasma insulin and glucose concentrations, and GIR are shown in Table 1. As shown in Fig. 1, although

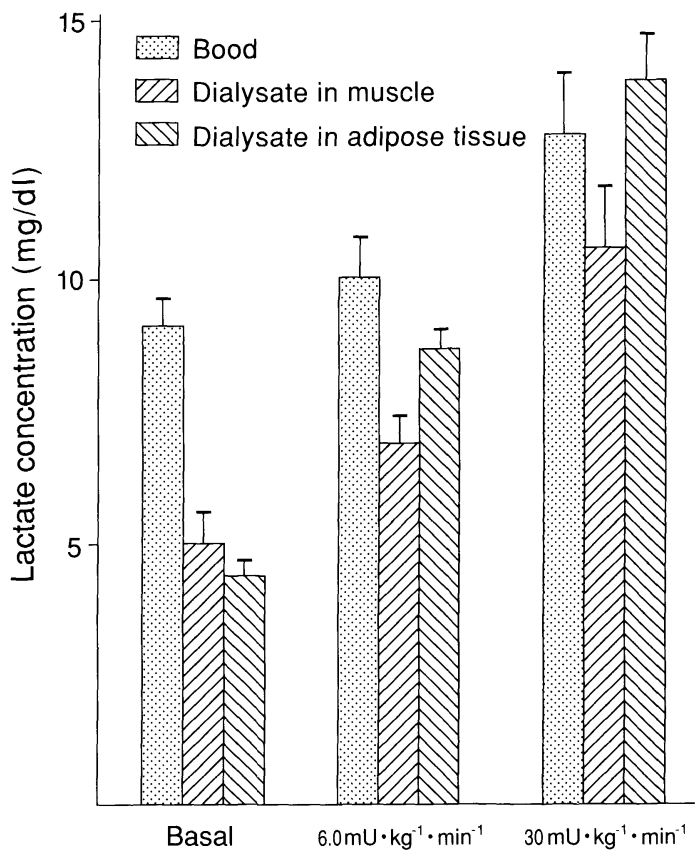

Fig. 1. Results of a preparatory experiment. Concentration of lactate in blood and dialysate in the muscle and adipose tissue at each insulin infusion rate $(0,6.0$ and 30.0 $\left.\mathrm{mU} \cdot \mathrm{kgBW}^{-1} \cdot \min ^{-1}\right)$. Six rats were used for this experiment.

Table 1. Plasma insulin and glucose concentrations and glucose infusion rate (GIR) during sequential euglycemic clamp in the preparatory experiment

\begin{tabular}{cccc}
\hline $\begin{array}{c}\text { Insulin } \\
\text { infusion rate } \\
\left(\mathrm{mU} \cdot \mathrm{kgBW}^{-1} \cdot \mathrm{min}^{-1}\right)\end{array}$ & $\begin{array}{c}\text { Insulin } \\
(\mu \mathrm{U} / \mathrm{m} l)\end{array}$ & $\begin{array}{c}\text { Glucose } \\
(\mathrm{mg} / \mathrm{d} l)\end{array}$ & $\begin{array}{c}\mathrm{GIR} \\
\left(\mathrm{mg} \cdot \mathrm{kgBW}^{-1} \cdot \mathrm{min}^{-1}\right)\end{array}$ \\
\hline 0 & $11.6 \pm 3.0$ & $70 \pm 2$ & \\
6.0 & $82.9 \pm 10.1$ & $68 \pm 2$ & $10.61 \pm 0.88$ \\
30.0 & $922.6 \pm 81.7$ & $68 \pm 3$ & $25.17 \pm 0.97$ \\
\hline
\end{tabular}

Values are the means \pm SEM. 
Table 2. Plasma insulin and glucose concentrations during $0,6.0$ and $30.0 \mathrm{mU} \cdot \mathrm{kgBW}^{-1} \cdot \mathrm{min}^{-1}$ insulin infusions

\begin{tabular}{cccccccc}
\hline \multicolumn{3}{c}{ BW (g) } & \multicolumn{3}{c}{ Insulin $(\mu \mathrm{U} / \mathrm{ml})$} & \multicolumn{3}{c}{ Glucose $(\mathrm{mg} / \mathrm{d} l)$} \\
\hline \multicolumn{2}{c}{$\begin{array}{c}\text { Insulin } \\
\text { infusion rate } \\
\left(\mathrm{mU}^{2} \mathrm{kgBW}^{-1} \cdot \mathrm{min}^{-1}\right)\end{array}$} & 0 & 6.0 & 30.0 & 0 & 6.0 & 30.0 \\
\hline ADMX (8) & $253 \pm 11$ & $10.2 \pm 3.2$ & $84.7 \pm 8.9$ & $931.0 \pm 79.3$ & $68 \pm 3$ & $64 \pm 3$ & $71 \pm 4$ \\
SHAM (10) & $263 \pm 16$ & $13.9 \pm 5.1$ & $93.4 \pm 19.1$ & $1064.4 \pm 93.8$ & $73 \pm 3$ & $68 \pm 3$ & $68 \pm 3$ \\
\hline
\end{tabular}

Values are the means \pm SEM. The number of rats is shown in parentheses.

there was no significant difference, blood lactate concentrations tended to increase during the three-step euglycemic clamp. A dose-dependent increase in the dialysate lactate concentration was also found in both muscle and adipose tissue.

\section{Effects of $A D M X$}

1) Catecholamines: Plasma epinephrine concentrations were significantly lower in ADMX rats $(0.02 \pm 0.01 \mathrm{ng} / \mathrm{m} l)$ than in SHAM rats $(0.28 \pm 0.04$ $\mathrm{ng} / \mathrm{m} l)(P<0.001)$. On the other hand, ADMX produced a significant rise in the plasma concentrations of norepinephrine $(1.14 \pm 0.13 \mathrm{ng} / \mathrm{ml})$, compared with SHAM rats $(0.44 \pm 0.11 \mathrm{ng} / \mathrm{ml})$ $(P<0.01)$.

2) Insulin and glucose (Table 2): The ADMX and SHAM treatment did not affect fasting plasma insulin or glucose levels. There was no significant difference between ADMX and SHAM rats in the steady-state plasma insulin or glucose concentrations during the euglycemic clamp. Plasma insulin concentrations at an insulin infusion rate of $0,6.0$ and $30.0 \mathrm{mU} \cdot \mathrm{kgBW}^{-1} \cdot \mathrm{min}^{-1}$ were $8-18,80-120$ and $800-1,200 \mu \mathrm{U} / \mathrm{ml}$, respectively.

3) GIR (Fig. 2): During no insulin infusion (rate $=0 \mathrm{mU} \cdot \mathrm{kgBW}^{-1} \cdot \mathrm{min}^{-1}$ ) GIR was not given to either group, because the plasma glucose concentrations were kept at fasting levels. GIR was significantly $(P<0.01)$ higher in ADMX $\left(13.41 \pm 0.82 \mathrm{mg} \cdot \mathrm{kgBW}^{-1} \cdot \mathrm{min}^{-1}\right)$ than in SHAM rats $\left(10.12 \pm 0.87 \mathrm{mg} \cdot \mathrm{kgBW}^{-1} \cdot \mathrm{min}^{-1}\right)$ at an insulin infusion rate of $6.0 \mathrm{mU} \cdot \mathrm{kgBW}^{-1} \cdot \mathrm{min}^{-1}$. However, there was no significant change in the difference between ADMX and SHAM rats during the hyperinsulinemic euglycemic clamp at an insulin infusion rate of $30.0 \mathrm{mU} \cdot \mathrm{kgBW}^{-1} \cdot \mathrm{min}^{-1}$.

4) Microdialysis in skeletal muscle (Fig. 3): Insulin stimulated lactate formation in a dose-

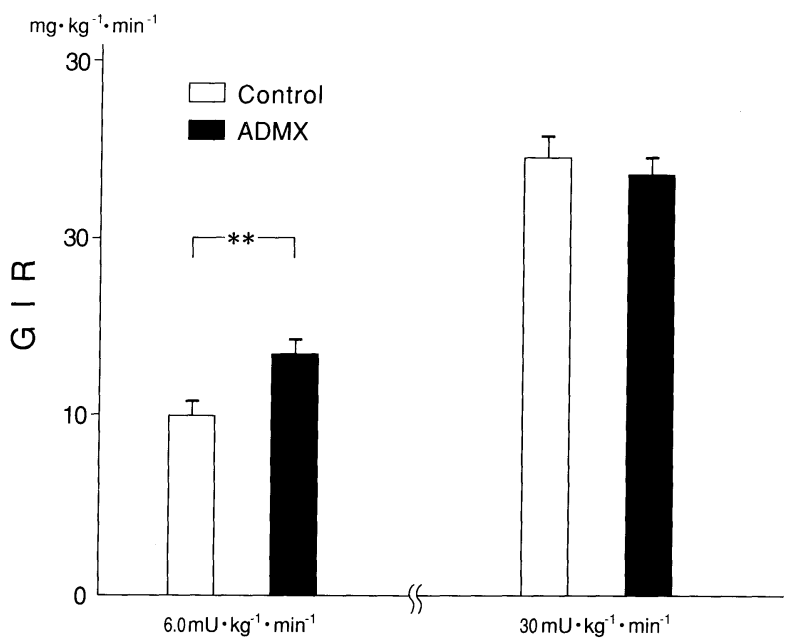

Fig. 2. Glucose infusion rate (GIR) during the 6.0 and $30.0-\mathrm{mU} \cdot \mathrm{kgBW}^{-1} \cdot \mathrm{min}^{-1}$ insulin infusions in ADMX $(n=8)$ and SHAM $(n=10)$ rats. Eight ADMX and ten SHAM rats were used. ${ }^{* *}, P<0.01 ; \mathrm{n}$, number of rats.

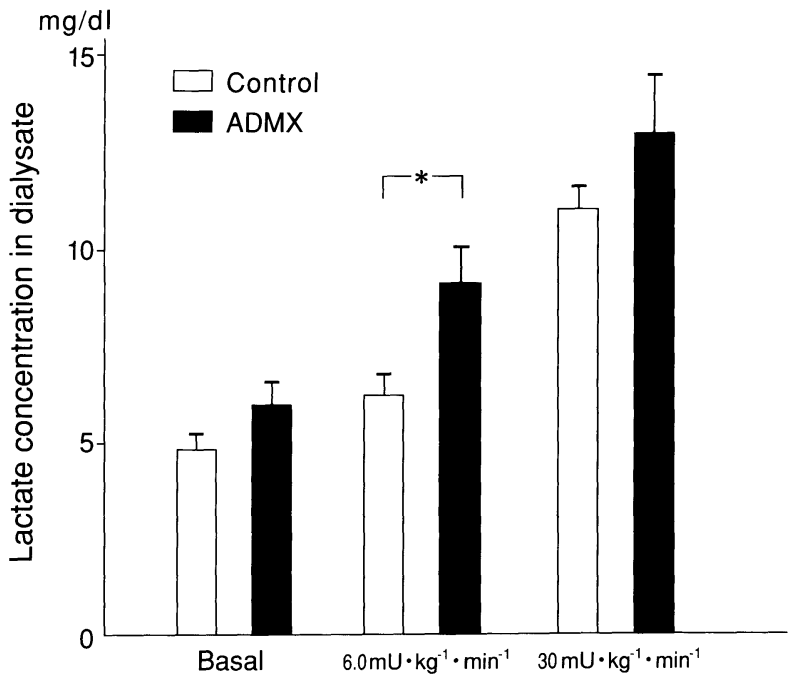

Fig. 3. Lactate concentrations in dialysate obtained by means of the microdialysis technique in skeletal muscle in $\operatorname{ADMX}(\mathrm{n}=8)$ and SHAM $(\mathrm{n}=10)$ rats. ${ }^{*}, P<0.05 ; \mathrm{n}$, number of rats. 


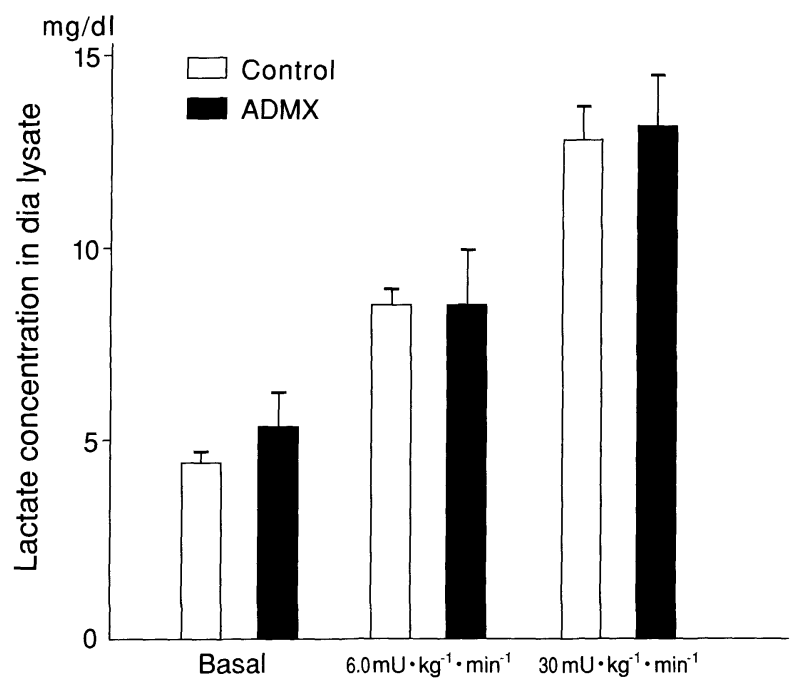

Fig. 4. Lactate concentrations in dialysate obtained by means of the microdialysis technique in adipose tissue in $\operatorname{ADMX}(n=8)$ and SHAM $(n=10)$ rats. $n$, number of rats.

dependent manner. The tendency was toward higher levels in ADMX rats throughout the study. During the basal plasma insulin concentrations and the $30-\mathrm{mU} \cdot \mathrm{kgBW}^{-1} \cdot \mathrm{min}^{-1}$ insulin clamp procedure, the lactate concentrations were not significantly different in ADMX and SHAM rats. However, during the $6.0-\mathrm{mU} \cdot \mathrm{kgBW}^{-1} \cdot \mathrm{min}^{-1}$ insulin infusion, the lactate concentrations in ADMX rats $(9.29 \pm 1.01 \mathrm{mg} / \mathrm{d} l)$ were significantly higher than those in SHAM rats $(6.22 \pm 0.47 \mathrm{mg} / \mathrm{d} l)$ $(P<0.05)$.

5) Microdialysis in adipose tissue (Fig. 4): A dose-dependent increase in insulin-stimulated lactate formation was observed as seen in skeletal muscle. No significant difference between lactate concentrations in ADMX and SHAM rats was found at insulin infusion rate of $0,6.0$ or 30.0 $\mathrm{mU} \cdot \mathrm{kgBW}^{-1} \cdot \mathrm{min}^{-1}$.

\section{Discussion}

The principal findings of the present study were that 1) the microdialysis technique provides a reliable estimate for insulin action in skeletal muscle and adipose tissue, 2) in the sequential euglycemic clamp, GIR was significantly higher in ADMX rats than in SHAM rats under the condition of a submaximal stimulating insulin concentration (insulin infusion rate: $6.0 \mathrm{mU} \cdot \mathrm{kgBW}^{-1}$. $\min ^{-1}$ ), and the lack of a significant difference between ADMX and SHAM rats was found during the $30-\mathrm{mU} \cdot \mathrm{kgBW}^{-1} \cdot \mathrm{min}^{-1}$ insulin infusion, and 3) by using a microdialysis technique, there was a dose-dependent increase in the dialysate lactate concentration in muscle and adipose tissue when insulin was infused. ADMX produced a significant increase in lactate production in skeletal muscle, not in adipose tissue, during the 6.0$\mathrm{mU} \cdot \mathrm{kgBW}^{-1} \cdot \mathrm{min}^{-1}$ insulin infusion.

The euglycemic clamp technique has proven to be useful in quantifying in vivo insulin action at the whole-body level in humans $[17,18]$. Kraegen $e t a l$. [19] developed a method for studying the in vivo action to intravenous insulin in intact and conscious rats. In order to obtain insulin doseresponse curves related to the whole-body glucose metabolism of the individual rats, we have modified the method of Kraegen et al. [19].

On the other hand, the microdialysis technique, developed by Ungerstedt et al.[10,11], is used to determine the neurotransmitters in the rat brain. Recently, Jansson et al. [13] and Hagström et al. [12] have applied this technique in human adipose tissue. The microdialysis probe is similar to a push-pull probe, but the perfusate is contained inside a semi-permeable membrane, and is not in direct contact with the tissue. After the placement of the probe into the tissue it is possible to monitor essentially any metabolic events taking place in the extracellular space or in the tissue. Therefore, the microdialysis technique provides a unique approach to follow ongoing metabolic changes at the cellular level in vivo [11].

In the basal insulin concentration, the dialysate concentration of lactate is mainly due to the blood concentration of lactate since the dialysate lactate concentrations corresponded to the blood lactate concentrations multiplied by in vitro dialysis recovery of lactate $(60.8 \pm 1.2 \%)$. However, during the euglycemic clamp, the dialysate concentration of lactate is mainly derived from tissue formation of lactate, because the dialysate lactate concentrations were much higher than blood lactate concentrations multiplied by in vitro dialysis recovery of lactate (Fig. 2).

By the way, the concentration of lactate in interstitial fluid represents the balance between the rate of delivery (by local production) and the clearance (by tissue uptake or blood flow). In the present study, therefore, it might be necessary to measure blood flow, and to demonstrate the 
possibility that the regional blood flow has been altered by ADMX or by glucose plus insulin infusion and that it has affected the tissue lactate concentration, since glucose ingestion has previously been shown to increase blood flow in adipose tissue [20, 21]. However, if blood flow was altered by ADMX or glucose plus insulin infusion, differences in the dialysate lactate level in both muscle and adipose tissue should be observed in ADMX and SHAM rats at any insulin infusion rate. The present study showed that a significant change in the dialysate lactate level in both groups was found only at the time of 6.0 $\mathrm{mU} \cdot \mathrm{kgBW}^{-1} \cdot \mathrm{min}^{-1}$ insulin infusion in skeletal muscle, but not in adipose tissue. Thus, the present study suggested that tissue blood flow changed similarly in both groups.

An increase in the blood and dialysate concentrations of lactate during the euglycemic clamp is probably due to increased production of lactate. Previous studies $[22,23]$ demonstrated that the majority of glucose in muscle and adipose tissue brought on by insulin stimulation was converted to lactate. With the euglycemic clamp, Scheidegger $e t$ $a l$. [24] found that chronic $\beta_{2}$-receptor stimulation increased insulin-stimulated glucose metabolism primarily as a result of increased nonoxidative glucose disposal. It is assumed that changes in the rate of glucose uptake are qualitatively reflected in the rate of lactate formation in these peripheral tissues [22]. Therefore, measuring the insulinstimulated glucose uptake by monitoring the formation of lactate by means of the microdialysis technique could be reliable. In the present study, the insulin-stimulated muscle and adipose tissue lactate formation was found in a dose-dependent manner. Furthermore, the maximal stimulation of glycolysis (lactate concentration in dialysate) by insulin observed in this work was 2-3 fold, which was similar to the previous work [22]. Therefore, the microdialysis technique provides a reliable estimate for determining the in vivo insulin action within individual tissues (skeletal muscle and adipose tissue).

The present study has provided evidence that ADMX caused a significant decrease in the plasma epinephrine concentration and a significant increase in the plasma norepinephrine concentration, which brought on a significant increase in insulin sensitivity in skeletal muscle (not adipose tissues), then resulted in a significant increase in the whole-body glucose uptake (GIR) at submaximal insulin concentrations. The plasma concentration of these catecholamines 1 week after ADMX in this study is consistent with the report of Ricordi et al. [9]. Deibert and DeFronzo [25] reported that epinephrine impaired the tissue sensitivity to insulin by using the hyperinsulinemic euglycemic clamp technique. Chiasson et al. [26] indicated that epinephrine suppressed the insulinstimulated glucose uptake in perfused hindlimbs of rats. Moreover, Lupien et al. [8] provided evidence that chronic norepinephrine infusion was associated with increased basal glucose turnover and increased insulin sensitivity of peripheral tissue in rats by means of the euglycemic clamp technique. These studies are in agreement with our present results showing that ADMX, which caused a significant change in the catecholamines, increased insulin sensitivity at the whole-body level by means of the euglycemic clamp. A likely explanation for the marked effect of ADMX on insulin sensitivity is that it is predominantly mediated via $\beta$-adrenergic pathways, because Lupien $e t$ $a l$. [8] and Scheidegger et al. [24] suggested that the effects of chronic administration of norepinephrine and terbutaline sulfate on in vivo glucose utilization were mediated by the $\beta$ adrenoceptor agonist activity of these agents.

Because the major portion of the glucose infused during a hyperinsulinemic euglycemic clamp is taken up by skeletal muscle [27], the improved insulin sensitivity in vivo most likely reflects an increase in insulin-stimulated glucose uptake in skeletal muscle. One proposed mechanism for the increased glucose uptake in skeletal muscle of ADMX rat is lowered muscle glycogen content and increased glycogen synthase activity $[8,26]$. Recently, Marette and Bukowiecki [7] showed that norepinephrine $\left(10^{-8} \mathrm{M}\right)$ significantly potentiated submaximal insulin responses for glucose transport in isolated rat brown adipocytes. Our results did not indicate the difference between ADMX and SHAM rats in muscle glycogen content or lactate formation in other muscle and adipose tissues. Therefore, the present study also, by means of the microdialysis technique, demonstrated in vivo that the increase in GIR in ADMX rat was partly explained by the increase in lactate formation in skeletal muscle. 


\section{Acknowledgments}

The authors wish to thank Ms. R. Kondo and Ms. Y. Tanaka for typing the manuscript and Ms.
M. Yamada for assays of lactate. These studies were supported, in part, by Meiji Life Foundation of health and welfare, and Uehara Memorial Foundation.

\section{References}

1. Porte D (1967) A receptor mechanism for the inhibition of insulin release by epinephrine in man. J Clin Invest 46: 86-94.

2. Sacca L, Sherwin R, Felig P (1987) Effect of sequential infusions of glucagon and epinephrine on glucose turnover in the dog. Am J Physiol 235 (Endocrinol Metab Gastrointest Physiol 5): E287E290.

3. Exton JH, Robinson GA, Sutherland EW, Park CR (1971) Studies on the role of adenosine 3', 5'monophosphate in the hepatic actions of glucagon and catecholamines. J Biol Chem 246: 6166-6177.

4. Sherline P, Lynch A, Glinsmann WH (1972) Cyclic AMP and adrenergic receptor control of rat liver glycogen metabolism. Endocrinology 91: 680-690.

5. Sloan I, Saul P, Bihler I (1978) Influence of adrenalin on sugar transport in soleus a red skeletal muscle. Mol Cell Endocr 10: 3-12.

6. Racotta R, Ramirez-Altamirano L, VelascoDelgado E (1986) Metabolic effects of chronic infusions of epinephrine and norepinephrine in rats. Am J Physiol 250 (Endocrinol Metab 13): E518E522.

7. Marette A, Bukowiecki LJ (1989) Stimulation of glucose transport by insulin and norepinephrine in isolated rat brown adipocytes. Am J Physiol (Cell Physiol 26) C714-C721.

8. Lupien JR, Hirshman MF, Horton ES (1990) Effects of norepinephrine infusion on in vivo insulin sensitivity and responsiveness. Am J Physiol 259 (Endocrinol Metab 22): E210-E215.

9. Ricordi C, Shah SD, Lacy PE, Clutter WE, Cryer PE (1988) Delayed extra-adrenal epinephrine secretion after bilateral adrenalectomy in rats. $\mathrm{AmJ}$ Physiol (Endocrinol Metab 17): E52-E53.

10. Ungerstedt $\mathrm{U}$, Herrera-Marsch M, Jungnelius $\mathrm{U}$, Ståhle L, Tossman U, Zetterström T (1982) Dopamine synaptic mechanisms reflected in studies combining behavioral recordings and brain dialysis. In: Kohsaka M (ed) Advances in the Biosciences: Advances in Dopamine Research. Pergamon Press, Oxford and New York.

11. Ungerstedt U (1986) Microdialysis-A new bioanalytical sampling technique. Current Separations 7: 43-46.

12. Hagström E, Arner P, Ungerstedt U, Bolinder J (1990) Subcutaneous adipose tissue: a source of lactate production after glucose ingestion in hu- mans. Am J Physiol 258 (Endocrinol Metab 27): E888-E893.

13. Jansson P-A, Smith U, Lonnröth P (1990) Interstitial glycerol concentration measured by microdialysis in two subcutaneous regions in humans. Am J Physiol 258 (Endocrinol Metab 21): E918-E922.

14. Yatomi A, Iguchi A, Yanagisawa S, Matsunago H, Niki I, Sakamoto N (1987) Prostaglandins affect the central nervous system to produce hypoglycemia in rats. Endocrinology 121: 36-41.

15. Hales CN, Randle DJ (1963) Immunoassay of insulin with antibody precipitate. Biochem $J$ 88: 457-468.

16. Hjemdahl P, Daleskog M, Kahan T (1979) Determination of plasma catecholamines by high performance liquid chromatography with electrochemical detection: comparison with radioenzymatic method. Life Sci 25: 131-138.

17. DeFronzo RA, Tobin JD, Andres R (1979) Glucose clamp technique: a method for quantifying insulin secretion and resistance. Am J Physiol 237 (Endocrinol Metab Gastrointest Physiol 6) E214-E223.

18. Oshida Y, Yamanouchi K, Hayamizu S, Sato Y (1989) Long-term mild jogging increases insulin action despite no influence on body mass index or $\mathrm{VO}_{2}$ max. J Appl Physiol 66: 2206-2210.

19. Kraegen EW, James DE, Bennett SP, Chisholm DJ (1983) In vivo insulin sensitivity in the rat determined by euglycemic clamp. Am J Physiol (Endocrinol Metab 8) E1-E7.

20. Bülow J, Astrup A, Christensen NJ (1987) A blood flow in skin, subcutaneous adipose tissue and skeletal muscle in the forearm of normal man during an oral glucose load. Acta Physiol Scand 130: 657-661.

21. Simonsen L, Bülow J, Astrup A, Madsen J, Christensen NJ (1990) Diet-induced changes in subcutaneous adipose tissue blood flow in man: effect of $\beta$-adrenoceptor inhibition. Acta Physiol Scand 139: 341-346.

22. Espinal J, Dohn L, Newsholm EA (1983) Sensitivity to insulin of glycolysis and glycogen synthesis of isolated soleus-muscle strips from sedentary, exercised and exercise-trained rats. Biochem J 212: 453-458.

23. Mårin P, Rubuffe-Scrive M, Björntorp P (1987) Glucose uptake in human adipose tissue. Metabolism 36: 1154-1160. 
24. Sheidegger K, Robbins DC, Danforth E Jr (1984) Effects of chronic beta receptor stimulation on glucose metabolism. Diabetes 33: 1144-1149.

25. Deibert DC, DeFronzo RA (1980) Epinephrineinduced insulin resistance in man. J Clin Invest 65: 717-721.

26. Chiasson J-L, Shikata H, Chu DTW, Exton JH (1981) Inhibitory effect of epinephrine on insulin- stimulated glucose uptake in rat skeletal muscle. $J$ Clin Invest 68: 706-713.

27. DeFornzo RA, Jacot E, Jequier E, Maeder E, Wahren J, Felber JP (1981) The effect of insulin and the disposal of intravenous glucose. Results from indirect calorimetry and hepatic and femoral venous catheterization. Diabetes 30: 1000-1007. 